\title{
MENINGKATKAN KOMPETENSI GURU MENYUSUN RENCANA PELAKSANAAN PEMBELAJARAN MELALUI PEMBIMBINGAN MODEL "LIMA-SI"
}

\author{
ARIYATI \\ Korwil Disdikbud Kecamatan Secang Kabupaten Magelang \\ e-mail: aariyatiari@gmail.com
}

\begin{abstract}
ABSTRAK
Penelitian ini dilaksanakan berdasarkan kenyataan bahwa kemampuan guru Gugus Sultan Agung dalam menyusun RPP sesuai kaidah masih sangat rendah. Salah satu penyebabnya adalah kurangnya pembimbingan dari pengawas sekolah. Untuk mengatasi masalah tersebut peneliti selaku pengawas melaksanakan kegiatan pembimbingan yang dikemas dalam bentuk penelitian tindakan sekolah. Penelitian dilaksanakan dalam dua siklus. Pembimbingan dilakukan dengan model "Lima-si" yang terdiri dari kegiatan presentasi, diskusi, supervisi, konsultasi, dan evaluasi. Rumusan masalah dalam penelitian ini adalah bagaimana proses pembimbingan, berapa besar peningkatan kemampuan guru menyusun RPP setelah pembimbingan dan ada tidaknya perubahan perilaku guru yang menyertai peningkatan kemampuannya menyusun RPP setelah pembimbingan. Pembimbingan dimulai dari kegiatan presentasi oleh peneliti tentang cara mengembangkan RPP sesuai Standar Proses, dilanjut kegiatan diskusi peserta menyusun RPP. Selanjutnya dilakukan supervisi yang ditindaklanjuti dengan konsultasi. Hasil konsultasi adalah perbaikan RPP buatan guru yang kemudian hasil perbaikan tersebut dievaluasi. Dengan melaksanakan pembimbingan tersebut dalam dua siklus, terbukti terdapat peningkatan kemampuan guru menyusun RPP sebesar 19,89\%. Peningkatan kemampuan guru menyusun RPP tersebut juga diikuti perubahan perilaku ke arah yang lebih baik. Perubahan perilaku utamanya pada motivasi diri guru yang semakin kuat sebanding dengan motivasi peneliti untuk menyajikan yang terbaik dalam kegiatan pembimbingan
\end{abstract}

Kata kunci: kompetensi guru, rencana pelaksanaan pembelajaran, pembimbingan model "Lima-si"

\section{PENDAHULUAN}

Salah satu tugas pokok guru adalah melaksanakan kegiatan pembelajaran. Pelaksanaan pembelajaran harus didahului dengan penyusunan perencanaan pembelajaran berupa Rencana Pelaksanaan Pembelajaran (RPP). Kunandar dalam Zendrato (2016) mengatakan bahwa Rencana Pelaksanaan Pembelajaran sebenarnya merupakan rencana yang menggambarkan prosedur dan pengorganisasian pembelajaran. Rencana tersebut digunakan untuk mencapai satu kompetensi dasar yang ditetapkan dalam Standar Isi dan dijabarkan dalam silabus.

Sementara itu Masaong (2013) mengatakan bahwa Rencana Pelaksanaan Pembelajaran merupakan realisasi dari pengalaman belajar siswa. Pengalaman belajar siswa yang dikembangkan adalah pengalaman belajar yang telah ditetapkan dalam silabus. Silabus diturunkan dari Standar Isi. Selain menggambarkan pengalaman belajar siswa, RPP juga menggambarkan kompetensi siswa yang akan dicapai. Pencapaian kompetensi tersebut diperoleh selama maupun setelah proses pembelajaran berlangsung.

Kedua pengertian tentang RPP di atas senada dengan yang terdapat di dalam Permendikbud nomor 22 tahun 2016 tentang Standar Proses dimana dikatakan bahwa RPP adalah rencana kegiatan pembelajaran tatap muka untuk satu pertemuan atau lebih. Menurut pengertian tersebut berarti RPP bisa disusun untuk lebih dari satu kali pertemuan. RPP dikembangkan dari silabus untuk mengarahkan kegiatan pembelajaran peserta didik dalam upaya mencapai kompetensi dasar.

Kegiatan perencanaan ini merupakan kegiatan awal yang harus dilakukan guru sebelum melaksanakan kegiatan pembelajaran. Sebagai tenaga profesional guru harus mampu merancang kegiatan pembelajaran. Sebagai perancang pembelajaran guru bertugas membuat 
rancangan program pembelajaran yang menjadi tanggung jawabnya. Program dibuat untuk mencapai standar kompetensi yang telah ditetapkan (Wahyuni dan Ibrahim, 2012: 11-12).

Dalam Undang-Undang Nomor 20 tahun 2003 tentang Sistem Pendidikan Nasional Bab XI pasal 39 ayat 2 dikatakan bahwa pendidik merupakan tenaga profesional yang bertugas merencanakan dan melaksanakan proses pembelajaran, menilai hasil pembelajaran, melakukan pembimbingan dan pelatihan, serta melakukan penelitian dan pengabdian kepada masyarakat, terutama bagi pendidik pada perguruan tinggi. Sejalan dengan hal tersebut USAID dalam Masaong (2013) mengatakan bahwa dalam pelaksanaan pembelajaran diperlukan kompetensi profesional guru di bidang perencanaan, proses pembelajaran, pengelolaan kelas, dan prosedur penilaian. Lebih lanjut disampaikan bahwa perencanaan melibatkan pemahaman terhadap karakteristik siswa untuk menyusun strategi dan langkah untuk mencapai tujuan.

Hastuti (2019) menyatakan bahwa kemampuan guru menyusun RPP belum baik. Hal tersebut diantaranya disebabkan oleh pemahaman guru terhadap cara menyusun RPP masih sangat kurang. Pemahaman yang masih kurang terutama dalam hal merumuskan indikator yang sesuai dengan kompetensi dasar dan merumuskan tujuan pembelajaran yang sesuai dengan indikator. Hal ini tentu saja berdampak pada kualitas perencanaan dan pelaksanaan pembelajaran yang dirancang dan dilaksanakan oleh para guru.

Di sisi lain Mawardi (2019) menyatakan bahwa kompetensi guru dalam menyusun RPP yang merupakan perencanaan operasional pembelajaran, masih rendah. Rendahnya kompetensi tersebut diakibatkan oleh rendahnya pemahaman guru tentang pengembangan komponenkomponnen RPP. Sebagian besar guru sebenarnya memiliki motivasi yang kuat untuk memiliki kompetensi yang memadai terkait dengan pengembangan RPP. Sebagai bukti mereka tetap berusaha untuk memperoleh dan meningkatkan pengetahuan mereka tentang cara mengembangkan RPP. Kompetensi tersebut mereka kembangkan dengan cara mengikuti pelatihan. Pelatihan yang mereka ikuti bisa dilaksanakan melalui KKG maupun melalui keikutsertaan pada pelatihan di instansi lain secara mandiri. Selain itu kemampuan mengembangkan RPP juga dilakukan dengan cara berbagi dengan guru lainnya.

Sementara itu Dewi (2020) menyampaikan bahwa kesulitan guru dalam menyusun RPP di antaranya disebabkan karena penguasaan IT guru yang masih rendah. Selain itu juga disebabkan karena kebiasaan mereka mengkopi langsung RPP dari internet. Kesulitan lainnya adalah dalam hal menetapkan metode pembelajaran. Sedangkan upaya yang dilakukan kepala sekolah dalam menghadapi kesulitan yang dialami guru dalam menyusun RPP antara lain dengan melakukan pelatihan terhadap guru yang masih mengalami kesulitan dalam penguasaan IT, melakukan supervisi dengan cara meminta guru untuk menyusun RPP sendiri, dan mengikutsertakan guru dalam kegiatan KKG.

Hasil studi dokumen yang dilakukan peneliti menunjukkan adanya permasalahan yang dihadapi guru dalam penyusunan RPP. Melalui kegiatan pemantauan implementasi Standar Nasional Pendidikan terhadap RPP yang disusun guru pada Gugus Sultan Agung Kecamatan Grabag semester 1 tahun pelajaran 2018/2019, terdapat beberapa permasalahan yang perlu kegiatan tindak lanjut. Dari 30 guru yang terdapat di Gugus Sultan Agung, hannya 5 orang guru yang menyusun RPP terdiri dari 13 komponen lengkap. Dalam penyusunan tujuan pembelajaran banyak yang belum memenuhi kaidah. Terdapat 20 guru yang belum menyusun tujuan pembelajaran dengan baik. Guru banyak yang belum mampu menurunkan indikator pencapaian kompetensi dari kompetensi dasar.

Langkah-langkah pembelajaran yang dibuat oleh guru untuk kegiatan pendahuluan kebanyakan belum mencantumkan penjelasan tentang tujuan pembelajaran dan kegiatan yang akan dilaksanakan. Untuk kegiatan inti belum mencantumkan sintaks model pembelajaran yang sesuai dengan model pembelajaran yang direncanakan. Untuk kegiatan penutup kebanyakan guru belum mencantumkan rencana kegiatan untuk pertemuan selanjutnya. Kurangnya kemampuan guru menyusun RPP sesuai kaidah, tidak lepas dari kurangnya pembimbingan yang dilakukan oleh pengawas sekolah. 
Berdasar kenyataan tersebut peneliti melaksanakan kegiatan pembimbingan model "Lima-Si" pada semester 2 tahun pelajaran 2018/2019. Model ini peneliti kembangkan sendiri dengan merujuk pada langkah-langkah pembimbingan yang terdiri dari presentasi, diskusi, supervisi, konsultasi, dan evaluasi. Model pembimbingan ini sangat mungkin dikembangkan di Gugus Sultan Agung. Hal tersebut didasarkan pada pertimbangan bahwa guru-guru pada Gugus Sultan Agung sangat kooperatif, didukung oleh kepala sekolah yang responsif.

Tujuan ditulisnya penelitian ini adalah untuk: 1) mendeskripsikan proses pembimbingan penyusunan RPP dengan model "Lima-si", 2) mengetahui berapa besar peningkatan kemampuan guru menyusun RPP setelah mengikuti pembimbingan dengan model 'Lima-si', dan 3) mendeskripsikan perubahan perilaku guru yang menyertai peningkatan kemampuannya menyusun RPP setelah mengikuti kegiatan pembimbingan dengan model "Lima-si". Manfaat dari penulisan penelitian ini: 1) bagi guru, menjadi motivasi untuk meningkatkan kompetensi profesionalnya; 2) bagi kepala sekolah, menjadi model yang bisa dikembangkan dalam melaksanakan pembimbingan terhadap guru; dan 3) bagi peneliti, memberikan kontribusi keilmuan yang bisa dikembangkan dalam melakukan penelitian materi sejenis.

\section{METODE PENELITIAN}

Penelitian ini dirancang dalam bentuk penelitian tindakan sekolah yang dilaksanakan dalam dua siklus. Masing-masing siklus terdiri dari empat tahapan yaitu perencanaan, tindakan, observasi, dan refleksi. Pada penelitian tindakan sekolah ini diterapkan pembimbingan dengan model "Lima-si". Model tersebut terdiri dari kegiatan presentasi, diskusi, supervisi, konsultasi, dan evaluasi. Indikator kinerja dalam penelitian ini ditetapkan sebesar 75\%. Desain Penelitian Tindakan Sekolah ini dapat digambarkan dalam bentuk bagan berikut:

1. Perencanaan

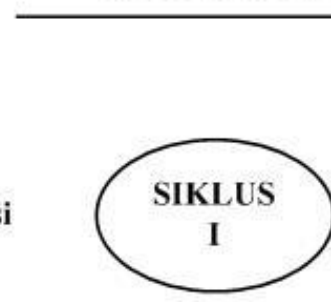

3. Pengamatan

\section{Perencanaan}

\section{Gambar 1. Disain Penelitian Tindakan Sekolah}

4. Refleksi

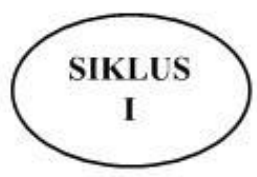

2. Tindakan

Presentasi dilakukan oleh peniliti dalam rangka membekali peserta tentang cara menyusun Rencana Pelaksanaan Pembelajaran (RPP). Selanjutnya diskusi dilakukan oleh peserta dalam rangka menyusun RPP. Setelah RPP selesai disusun dilakukan supervisi oleh pengawas selaku peneliti bekerja sama dengan kepala sekolah selaku kolaborator. Hasil supervisi selanjutnya dianalisis untuk menentukan tindak lanjut. Sebagai tindak lanjut hasil supervisi dilakukan konsultasi. Pada kegiatan ini peserta dalam hal ini guru melakukan konsultasi dengan pengawas selaku peneliti untuk perbaikan penyusunan RPP. RPP buatan guru hasil konsultasi selanjutnya dievaluasi.

Pelaksanaan penelitian siklus II didasarkan pada refleksi siklus I. Pada siklus II Presentasi dilakukan fokus pada materi yang belum dikuasai peserta sedang pada siklus I peneliti menyampaikan materi penyusunan RPP secara umum. Untuk kegiatan konsultasi siklus I dilaksanakan berbasis sekolah, sedangkan untuk siklus II konsultasi dilaksanakan berbasis kelas. Dua perbedaan mendasar dalam pelaksanaan tindakan tersebut dilaksanakan dalam rangka memberikan pemahaman lebih baik kepada peserta pembimbingan. 


\section{Hasil Penelitian Siklus I}

Pembimbingan siklus I dilaksanakan pada bulan Januari 2019. Kegiatan pembimbingan dilakukan terhadap guru kelas pada Gugus Sultan Agung. Gugus Sultan Agung terdiri dari lima sekolah yaitu SDN Kayupuring sebagai SD Inti, SDN Kalikuto, SDN Banyusari, SDN Grabag 3, dan SDN Kartoharjo sebagai SD imbas. Terdapat 30 orang guru kelas pada Gugus Sultan Agung.

Untuk kegiatan presentasi dilaksanakan di SDN Kayupuring selaku SD Inti. Pada kegiatan ini juga dilakukan observasi baik oleh peneliti maupun oleh kolaborator untuk mengamatai perilaku peserta pembimbingan. Data hasil observasi akan menggambarkan perilaku guru selama mengikuti pembimbingan. Untuk kegiatan konsultasi dilaksanakan berbasis sekolah di semua sekolah secara terjadwal. Hasil analisa terhadap RPP buatan guru yang disusun setelah mengikuti kegiatan pembimbingan siklus I dapat ditampilkan pada tabel 2 berikut:

Tabel 2. Hasil Analisa RPP Siklus I

\begin{tabular}{|c|c|c|c|c|}
\hline \multirow[t]{2}{*}{ NO } & \multirow[t]{2}{*}{ ASPEK } & \multicolumn{3}{|c|}{$\begin{array}{l}\text { SKOR DAN } \\
\text { JUMLAH GURU }\end{array}$} \\
\hline & & 0 & 1 & 2 \\
\hline 1 & Identitas mata pelajaran & 0 & 21 & 9 \\
\hline 2 & Indikator Pencapaian Kompetensi & 0 & 18 & 12 \\
\hline 3 & Tujuan Pembelajaran & 0 & 19 & 11 \\
\hline 4 & Materi Ajar & 0 & 18 & 12 \\
\hline 5 & $\begin{array}{l}\text { Kesesuaian alokasi waktu dengan cakupan } \\
\text { materi }\end{array}$ & 0 & 4 & 26 \\
\hline 6 & Pendekatan Pembelajaran & 3 & 0 & 27 \\
\hline 7 & Model Pembelajaran & 4 & 0 & 28 \\
\hline 8 & Metode Pembelajaran & 0 & 22 & 8 \\
\hline 9 & Sumber Belajar & 0 & 10 & 20 \\
\hline 10 & Media pembelajaran & 0 & 12 & 18 \\
\hline 11 & Kegiatan Pendahuluan Pembelajaran & 0 & 18 & 12 \\
\hline 12 & Kegiatan Inti Pembelajaran & 0 & 30 & 0 \\
\hline 13 & Kegiatan Penutup Pembelajaran & 0 & 14 & 16 \\
\hline 14 & Penilaian Pembelajaran & 0 & 30 & 0 \\
\hline
\end{tabular}

Berdasarkan data pada tabel 2, dapat diketahui bahwa pada siklus I masih terdapat aspek-aspek dimana guru belum mampu memanuhi kaidah pengembangan RPP sesuai Standar Proses. Aspek-aspek tersebut diantaranya pada aspek nomor 6 dan 7 yaitu tentang penetuan pendekatan pembelajaran dan model pembelajaran. Sedangkan pada aspek nomor 12 dan 14 yaitu untuk kegiatan inti pembelajaran dan penilaian pembelajaran semua guru belum dapat memenuhi kaidah dengan sempurna. Untuk aspek lainnya juga masih banyak guru yang belum mampu memenuhi kaidah sesuai Standar Proses.

Hasil penilaian terhadap RPP buatan guru pada siklus I diperoleh rerata sebesar 72,61 termasuk katagori cukup. Nilai tertinggi pada angka 89,28 dan nilai terendah pada angka 53,57. Perbandingan peserta dengan perolehan nilai tuntas dan tidak tuntas sebesar 1:1 dengan persentase ketuntasan sebesar 50\%. Distribusi hasil penilaian RPP siklus I selengkapnya dapat ditampilkan pada tabel 3 berikut:

Tabel 3. Distribusi Hasil Penilaian RPP Siklus I

\begin{tabular}{|c|c|c|}
\hline No & Uraian & Hasil \\
\hline 1 & Nilai Tetinggi & 89,28 \\
\hline 2 & Nilai Terendah & 53,57 \\
\hline 3 & Rerata & 72,61 \\
\hline
\end{tabular}




\begin{tabular}{lll}
\hline 4 & Persentase peserta yang tuntas & 50 \\
\hline 5 & Persentase peserta belum tuntas & 50 \\
\hline 6 & Persentase ketuntasan belajar & 50 \\
\hline
\end{tabular}

Refleksi siklus I didasarkan pada hasil pembimbingan penyusunan RPP dengan metode "Lima-si" pada siklus I. Secara umum telah diperoleh rerata kemampuan guru menyusun RPP setelah pembimbingan sebesar 72,61 termasuk kategori cukup. Masih terdapat beberapa aspek dalam RPP yang dalam pengembangannya guru belum maksimal. Pada aspek 6 dan 7 yaitu tentang penentuan pendekatan pembelajaran dan model pembelajaran masih terdapat guru yang sama sekali tidak mencantumkannya dalam RPP. Pada aspek ini perlu dilakukan penekanan. Sedangkan pada aspek nomor 12 dan 14 yaitu untuk kegiatan inti pembelajaran dan penilaian pembelajaran semua guru belum dapat memenuhi kaidah dengan sempurna. Untuk kedua aspek ini perlu dilakukan pendalaman lebih lanjut. Persentase ketuntasan pada siklus I sebesar 50\% belum melampaui indikator kinerja sebesar $75 \%$, oleh karena itu perlu dilaksanakan pembimbingan siklus II.

\section{Hasil Penelitian Siklus II}

Pembimbingan siklus II dilaksanakan berdasarkan hasil refleksi siklus I. Pembimbingan Siklus II dilaksanakan pada bulan Februari 2019. Kegiatan didahului dengan tahap persiapan yaitu dengan mempersiapkan instrumen penelitian dan sarana prasarana lainnya. Pada tahap pelaksanaan kegiatan diawali dengan presentasi oleh peneliti. Presentasi difokuskan pada materi yang belum dikuasai peserta dengan baik. Selanjutnya dilakukan diskusi peserta menyusun RPP. RPP hasil pembimbingan disupervisi kemudian dianalisis untuk menentukan tindak lanjut.

Tindak lanjut supervisi dilakukan dengan konsultasi. Kegiatan konsultasi pada siklus II dilakukan dengan penjadwalan berbasis kelas. Pada siklus II ini kelompok konsultasi terdiri dari kelompok guru kelas I, 2, 3, 4, 5, dan 6. Konsultasi dilakukan secara terjadwal di tempat yang disepakati bersama. Setelah kegiatan konsultasi peserta membuat RPP untuk dievaluasi. Kolaborator melakukan pengamatan terhadap aktivitas pembimbingan dan perilaku peserta pembimbingan. Hasil analisa terhadap RPP hasil pembimbingan siklus II dapat ditampilkan pada tabel 4 berikut:

Tabel 4. Hasil Analisa RPP Siklus II

\begin{tabular}{|c|c|c|c|c|}
\hline \multirow[t]{2}{*}{ NO } & \multirow[t]{2}{*}{ ASPEK } & \multicolumn{3}{|c|}{$\begin{array}{l}\text { SKOR DAN } \\
\text { JUMLAH GURU }\end{array}$} \\
\hline & & 0 & 1 & 2 \\
\hline 1 & Identitas mata pelajaran & 0 & 0 & 30 \\
\hline 2 & Indikator Pencapaian Kompetensi & 0 & 8 & 22 \\
\hline 3 & Tujuan Pembelajaran & 0 & 7 & 23 \\
\hline 4 & Materi Ajar & 0 & 0 & 30 \\
\hline 5 & $\begin{array}{l}\text { Kesesuaian alokasi waktu dengan cakupan } \\
\text { materi }\end{array}$ & 0 & 0 & 30 \\
\hline 6 & Pendekatan Pembelajaran & 0 & 0 & 30 \\
\hline 7 & Model Pembelajaran & 0 & 0 & 30 \\
\hline 8 & Metode Pembelajaran & 0 & 3 & 27 \\
\hline 9 & Sumber Belajar & 0 & 3 & 27 \\
\hline 10 & Media pembelajaran & 0 & 3 & 27 \\
\hline 11 & Kegiatan Pendahuluan Pembelajaran & 0 & 7 & 23 \\
\hline 12 & Kegiatan Inti Pembelajaran & 0 & 30 & 0 \\
\hline 13 & Kegiatan Penutup Pembelajaran & 0 & 0 & 30 \\
\hline 14 & Penilaian Pembelajaran & 0 & 27 & 3 \\
\hline
\end{tabular}


Dari data pada tabel 4 dapat diketahui bahwa masih terdapat aspek yang belum dikuasai oleh kebanyakan peserta dengan sempurna yaitu aspek nomor 12 dan 14 berkaitan dengan kegiatan inti pembelajaran dan penilaian pembelajaran. Masih terdapat materi yang belum dikuasai benar oleh peserta yaitu aspek nomor 2,3, dan 11. Ketiga aspek tersebut yaitu berkait dengan indikator pencapaian kompetensi, tujuan pembelajaran, dan kegiatan pendahuluan pembelajaran menjadi garapan peneliti sebagai pengawas untuk ditindaklanjuti dalam kegiatan kepengawasan.

Hasil penilaian RPP pada siklus II diperoleh rerata sebesar 92,5 dengan nilai tertinggi sebesar 96,42 dan nilai terendah sebesar 82,14. Untuk ketuntasan tercapai 100\%. Selengkapnya distribusi hasil penilaian RPP siklus II dapat ditampilkan pada tabel 5 berikut:

Tabel 5. Distribusi Hasil Penilaian RPP Siklus II

\begin{tabular}{|c|c|c|}
\hline No & Uraian & Hasil \\
\hline 1 & Nilai Tetinggi & 96,42 \\
\hline 2 & Nilai Terendah & 82,14 \\
\hline 3 & Rerata & 92,5 \\
\hline 4 & Persentase peserta yang tuntas & 100 \\
\hline 5 & Persentase peserta belum tuntas & 0 \\
\hline 6 & Persentase ketuntasan & 100 \\
\hline
\end{tabular}

Refleksi siklus II dilakukan dengan melihat hasil pembimbingan siklus II. Hasil pembimbingan siklus II dengan rerata 92,5 sudah melampaui indikator kinerja sehingga terget penelitian telah terlampaui. Berdasarkan hasil tersebut penelitian ini tidak perlu dilanjutkan dengan siklus berikutnya.

\section{Pembahasan}

Tujuan Penelitian Tindakan Sekolah ini adalah untuk mendeskripsikan proses pembimbingan dengan metode "Lima-si"; mengetahui seberapa besar peningkatan kemampuan guru menyusun RPP setelah mengikuti pembimbingan dengan metode "Lima-si" dan mendeskripsikan perubahan perilaku guru yang menyertai peningkatan kemampuannya menyusun RPP setelah mengikuti pembimbingan dengan metode "Lima-si'.

Proses pembimbingan dilaksanakan dalam dua siklus yang masing-masing siklus terdiri dari empat tahapan yaitu perencanaan, pelaksanaan, pengamatan, dan refleksi. Dalam tahap pelaksanaan dilaksanakan pembimbingan dengan metode "Lima-si" yang terdiri dari presentasi, diskusi, supervisi, konsultasi, dan evaluasi.

Berdasarkan refleksi siklus I, dilakukan perbaikan perlakuan pada siklus II. Perbaikan pertama dilakukan pada kegiatan presentasi yang dilakukan oleh peneliti. Pada presentasi siklus II ini difokuskan pada materi-materi yang belum dikuasai guru. Selanjutnya pada kegiatan konsultasi pembagian kelompok dilakukan sesuai kelas mengajarnya sehingga konsultasi bisa dilakukan lebih terfokus.

Dengan membandingkan hasil penelitian siklus I dan siklus II dapat diketahui terdapat peningkatan kemampuan guru dalam menyusun RPP setelah mengikuti kegiatan pembimbingan model "Lima-si". Dilihat dari 14 aspek yang dinilai dari RPP yang dibuat guru pada siklus II, terdapat 6 aspek yang memperoleh nilai sempurna yaitu aspek nomor: 1, 4, 5, 6, 7 dan 17. Pada ke enam aspek tersebut pada siklus II semua RPP buatan guru memperoleh nilai sempurna .

Terdapat satu unsur yang masih belum memuaskan hasilnya yaitu pada aspek nomor 12 tentang kegiatan inti pembelajaran. Untuk aspek ini RPP buatan guru pada siklus II semua memperoleh skor 1 . Hal tersebut disebabkan karena pada aspek ini guru belum mencantumkan sintaks pembelajaran sesuai model pembelajaran yang dipilih. Untuk materi ini akan menjadi garapan peneliti selaku pengawas pada kegiatan kepengawasan selanjutnya. 
Berdasarkan hasil penilaian terhadap RPP siklus I dan siklus II terdapat kenaikan kemampuan guru menyusun RPP yang cukup signifikan. Peningkatan kemampuan guru menyusun RPP dari siklus I ke siklus II dapat disajikan dalam grafik berikut:

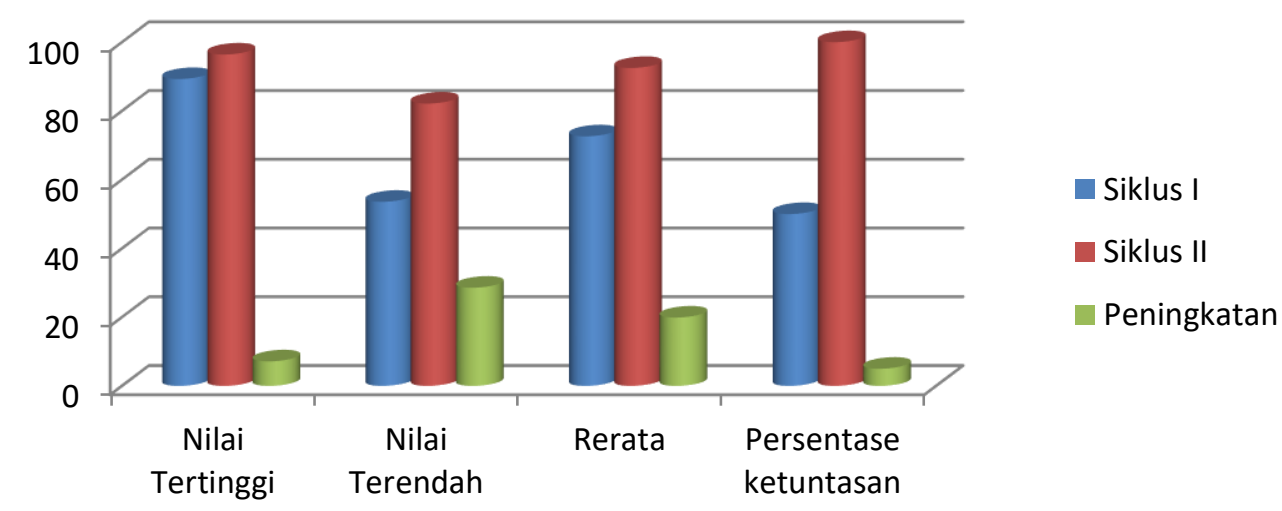

Gambar 2. Grafik Peningkatan Kemampuan Guru Menyusun RPP

Dari data yang terdapat pada gambar 2 tersebut, dapat diketahui secara umum kemapuan guru menyusun RPP setelah mengikuti kegiatan pembimbingan model "Lima-si", mengalami peningkatan. Hasil siklus I diperoleh rerata sebesar 72,61 termasuk kategori cukup, dan pada siklus II diperoleh rerata 92,5 termasuk kategori sangat baik. Terdapat kenaikan sebesar $19,89 \%$, termasuk angka kenaikan yang cukup signifikan. Hasil penelitian ini sejalan dengan pendapat Hastuti (2019) yang menyatakan Silabora dapat meningkatkan kemampuan guru dalam menyusun RPP sebesar 20,48\% dengan rata-rata kemampuan guru dalam menyusun RPP pada siklus I sebesar 56,66\% dan pada siklus II sebesar 66,67\%. Penelitian ini membuktikan bahwa dengan pembimbingan terhadap guru dalam meyusun RPP melalui model "Lima-si", dapat memberikan pemahaman terhadap guru tentang cara menyusun RPP terutama dalam merumuskan indikator yang sesuai dengan kompetensi dasar dan merumuskan tujuan pembelajaran yang sesuai indikator.

Hasil pengamatan kolaborator terhadap perilaku guru selama kegiatan pembimbingan menunjukkan bahwa, dengan kegiatan pembimbingan yang dilakukan dengan metode "Limasi”, dapat meningkatkan motivasi guru dalam menyusun RPP sesuai Standar Proses. Hal tesebut sejalan dengan pendapat Mawardi (2019) yang mengatakan bahwa guru sebenarnya memiliki motivasi yang kuat untuk memiliki kompetensi yang memadai terkait dengan RPP. Motivasi yang kuat tersebut sebanding dengan motivasi yang muncul dalam diri peneliti untuk memiliki bekal pengetahuan yang cukup dalam melakukan pembimbingan terhadap guru dalam mengembangkan RPP. Bekal pengetahuan yang cukup tersebut membuat peneliti tampil percaya diri dalam melaksanakan pembimbingan.

Hasil wawancara terhadap peserta pembimbingan memberikan gambaran bahwa kegiatan pembimbingan membantu peserta memahami cara mengembangkan RPP dengan jelas dan gamblang. Hal ini sejalah dengan hasil penelitian yang dilakukan oleh Zarkasi (2019) bahwa dalam rangka menggerakkan guru menyusun RPP, dilaksanakan kegiatan pembinaan yang menggunakan dua langkah solusi dalam mengatasi masalah. Langkah tersebut adalah dengan mengadakan workshop kemudian dibimbing secara berkelompok. Hasil penelitian menunjukkan bahwa kegiatan pembimbingan yang dilakukan menghasilkan peningkatan kemampuan guru menyusun RPP sekaligus meningkatnya motivasi guru. 


\section{KESIMPULAN}

Penelitian ini membuktikan bahwa kegiatan pembimbingan dengan model "Lima-si" dapat meningkatkan kemampuan guru menyusun rencana pelaksanaan pembelajaran. Proses pembimbingan yang dilakukan melalui lima kegiatan meliputi kegiatan presentasi, diskusi, supervisi, konsultasi, dan evaluasi tersebut, mampu membawa peserta lebih memahami proses penyusunan RPP dengan baik dan benar sesuai kaidah. Pengalaman tersebut memberikan peningkatan kemampuan guru sebesar 19,89\% dari siklus I sebesar 72,61\% ke siklus II sebesar 92,5\%. Peningkatan kemampuan guru tersebut juga diiringi dengan perubahan perilaku guru ke arah yang lebih baik. Perubahan mencolok pada motivasi untuk menjadi lebih baik dalam diri guru, yang muncul seiring dengan motivasi dalam diri peneliti untuk dapat menyajikan yang terbaik bagi peserta pelatihan. Berdasarkan simpulan tersebut peneliti menyampaikan saran utamanya kepada para pengawas untuk dapat menerapkan model pembimbingan ini pada materi yang lain.

\section{DAFTAR PUSTAKA}

Dewi, A.P. (2020). Kemampuan Guru Dalam Menyusun RPP Kurikulum 2013 di Sekolah Dasar. Skripsi. Program Studi Pendidikan Guru Sekolah Dasar Universitas Muhammadiyah. Surakarta.

Hastuti, B.D. (2012). Silabora Untuk Meningkatkan Kemampuan Guru Dalam Merencanakan dan Melaksanakan Pembelajaran Bagi Guru IPA SMP. Makasar: CV Pena Indis

Masaong. (2013). Supervisi Pembelajaran dan Pengembangan Kapasitas Guru. Bandung: Alfabeta.

Mawardi. (2019). Optimalisasi Kompetensi Guru Dalam Penyusunan Rencana Pelaksanaan Pembelajaran. Didaktika. 20(1), 69-82.

Permendikbud 2016 No. 22, Standar Proses Pendidikan Dasar dan Menengah.

Undang-Undang RI 2003 No. 20 tahun. Sistem Pendidikan Nasional

Wahyuni, S., \& Ibrahim, A. S. (2012). Perencanaan Pembelajaran Bahasa Berkarakter. Malang: Refika Aditama

Zarkasi, A. (2019). Peningkatan Kemampuan Guru Dalam Penyusunan RPP berbasis HOTS Melalui Workshop dan Pembimbingan di SMA Negeri Penajem Paser Utara. Kompetensi Universitas Balik Papan. 12(1)

Zendrato, J. (2016). Tingkat Penerapan Rencana Pelaksanaan Pembelajaran Dalam Pelaksanaan Pembelajaran di Kelas Suatu Studi Kasus di SMA Dian Harapan Jakarta. Scolaria. 6(2), 58-73 